\title{
Effect of altering the type of dietary carbohydrate early postpartum on reproductive performance and milk production in pasture-grazed dairy cows
}

\author{
S. McDougall, ${ }^{* 1}$ S. Leane, $†$ S. T. Butler, $†$ J. R. Roche, $\ddagger$ and C. R. Burke \\ ${ }^{*}$ Cognosco, Anexa FVC, Morrinsville, New Zealand, 3300 \\ †Animal and Grassland Research and Innovation Centre, Teagasc, Moorepark, Fermoy, Co. Cork, Ireland, P61 C996 \\ ‡DairyNZ Limited, Hamilton, New Zealand 3240
}

\begin{abstract}
The objective of this study was to assess the effect of increasing dietary starch for approximately $30 \mathrm{~d}$ postpartum on reproduction outcomes in pasture-grazed, seasonal-calving dairy cows. Cows $(\mathrm{n}=948)$ from 3 commercial herds were blocked by age $(2,3$, and $>3$ yr), breed, and expected calving date and randomly assigned to 1 of 2 postpartum treatment groups: high starch $(34.7 \pm 1.9 \%$ nonstructural carbohydrate; mean $\pm \mathrm{SD})$ or low starch $(22.5 \pm 0.4 \%$ nonstructural carbohydrate). The high-starch group in all 3 farms received 4.0 to $4.5 \mathrm{~kg} / \mathrm{d}$ of a $75: 25$ cracked corn:barley grain mixture in the dairy parlor, split evenly between the morning and afternoon milkings. The low-starch cows received 5.0 to $5.5 \mathrm{~kg} / \mathrm{d}$ of a $50: 50$ mixture of palm kernel meal:soy hulls (herds 1 and 3 ) fed in the parlor; low-starch cows in the remaining herd (herd 2) did not receive a concentrate feed. Cows were cograzed on ryegrass-white clover dominant pastures and were offered corn silage (herds 1 and 3) and canola, corn distillers grain, and palm kernel meal (herd 1) throughout the study. At 1 mo before the start of the seasonal breeding period, the high-starch supplement was removed, and within each herd treatment groups were managed similarly through breeding. Presence of purulent vaginal discharge was assessed at 28 DIM, and tail paint was assessed weekly from 2 to 6 wk postpartum for signs of estrus. The interval to first observed estrus was unaffected by treatment (32.7 vs. $33.5 \pm 2 \mathrm{~d}$ for high and low starch, respectively), but there were tendencies for a herd $\times$ treatment interaction for proportion of cows pregnant to first service and for pregnancy within $6 \mathrm{wk}$. This interaction was significant for the proportion of cows finally pregnant; a lower proportion of high-starch cows were pregnant to first service, pregnant by $6 \mathrm{wk}$,
\end{abstract}

Received December 8, 2016.

Accepted December 18, 2017.

${ }^{1}$ Corresponding author: smcdougall@anexafvc.co.nz and pregnant by the end of the seasonal breeding period in herd 1, but diet did not affect these outcomes in the other herds. Our results do not support a positive effect on reproduction from increasing dietary starch in seasonally bred grazing dairy cows. However, the interactions indicate variability in the herd response to dietary starch early postpartum and imply that pregnancy rate could potentially be compromised through the provision of starch to grazing dairy cows in early lactation (i.e., prebreeding). The experiment was not designed to define the reasons for these interactions, but differences should be considered in future research on the subject.

Key words: nonstructural carbohydrate, fertility, grazing dairy cow

\section{INTRODUCTION}

Following parturition, there is a substantial increase in nutrient requirements for milk production; nutrient intake does not meet these requirements, and cows enter a period of negative energy balance (Bauman and Currie, 1980; Bell, 1995). This negative energy balance has been implicated in reduced pregnancy success (Buckley et al., 2003; Roche et al., 2007, 2009); it is therefore plausible that providing grazing dairy cows with supplementary feeds in early lactation would improve reproductive success. However, increasing cow DMI through allocating a greater pasture allowance per cow or supplementing grazing cows with pasture silage (McDougall et al., 1995; Burke and Roche, 2007) or cereal grains, beet pulp, or corn gluten feed (Kennedy et al., 2002, 2003; Horan et al., 2005; Cutullic et al., 2011) has not improved reproductive performance when cows were grazed to optimize pasture management. A breed $\times$ energy intake interaction on BCS was reported when Swedish Reds and Holsteins were fed a high- or low-energy ration postpartum, wherein the high-energy diet was associated with higher BCS compared with the low-energy diet in the Swedish reds, whereas no 
difference in BCS was noted between the 2 diets in Holstein-Friesians (Ntallaris et al., 2017). A similar finding was reported in Holstein-Friesian strains from different selection indices, wherein selecting primarily for milk production reduced the effect of environment and nutrition on BCS compared with strains also selected for functional traits (Roche et al., 2006; McCarthy et al., 2007).

Instead of increasing feed allocation and DMI, however, it has been hypothesized that altering the ratio of structural to NSC in the diet without altering intake of ME could reduce the duration of postpartum anestrus (i.e., the postpartum anestrous period) and improve fertility outcomes through increasing circulating concentrations of insulin in dairy cows early postpartum. Consistent with this hypothesis, Gong et al. (2002) and Garnsworthy et al. (2009) reported greater conception rates and a higher proportion of cows pregnant by 120 d postcalving when they consumed a high-NSC diet from calving to first ovulation and a low-NSC diet subsequently. In another study in which cows were fed isoenergetic diets, higher NSC was associated with greater insulin concentrations, more small $(<5 \mathrm{~mm})$ ovarian follicles, and a tendency for greater progesterone concentrations and a larger corpus luteum diameter after ovulation (Garnsworthy et al., 2008). The greatest dietary NSC content, however, resulted in cows having lower progesterone and a smaller corpus luteum, possibly indicating a threshold level of dietary NSC, above which there are detrimental effects (Garnsworthy et al., 2008). Other postpartum dietary manipulation, such as increasing dietary fat in some forms, has also been demonstrated to improve pregnancy rates (Rodney et al., 2015).

Grazing dairy cows consume diets low in NSC and high in fermentable NDF and yet, to maintain seasonal milk production, are required to cycle early postcalving and have high first service conception rates (Roche et al., 2011). Therefore, it is hypothesized that grazing cows would benefit from supplementation with NSC postcalving. In support of this hypothesis, Burke et al. (2010) reported an 8-d shorter postpartum anestrous period and a $23 \%$ increase in first service conception rate in grazing dairy cows when diet NSC content was increased from 18 to $38 \%$ during the first 35 DIM. However, the experiment involved only 16 animals per group and was undertaken at 1 research facility; therefore, although the results were statistically significant and consistent with the previous reports from TMR feeding systems, the study requires validation on a larger scale and across varying farm systems to allow generalization of the findings. Accordingly, the objective of this current study was to assess whether increasing dietary starch content would improve reproduction in season- ally bred, pasture-grazed dairy cattle on commercially operated dairy farms.

\section{MATERIALS AND METHODS}

The study was conducted on 3 commercial springcalving dairy herds in New Zealand between July and October 2014. All herds had rotary milking parlors with automatic cow identification and in-parlor feeding systems that allowed cows to be individually offered a specific concentrate feed. Cows were managed on pasture and were allocated fresh pasture twice daily as part of an intensively managed rotational grazing system (Roche et al., 2017). All procedures and animal events had the prior approval of AgResearch Ruakura Animal Ethics Committee (Hamilton, New Zealand).

\section{Experimental Design}

Cows $(\mathrm{n}=948)$ were randomly assigned within herd to a high-NSC (high starch) or low-NSC (low starch) diet following blocking by age $(2,3,>3 \mathrm{yr})$, breed ( $>11 / 16$ th defined as either Holstein-Friesian or Jersey; the remainder defined as crossbreeds), and expected week of calving based on pregnancy diagnosis. A general description of the herds and cows enrolled in the study is provided in Tables 1 and 2, respectively.

\section{Nutritional Management}

A nutritional management program was developed for each herd in consultation with a nutritionist and the herd owner. The objective of the program was to

Table 1. Descriptive information of the 3 herds enrolled to examine the effects of feeding cows with a pasture-based diet designed to be high or low in NSC during the first 4 to $5 \mathrm{wk}$ of lactation on indicators of metabolism, health, and resumption of estrus

\begin{tabular}{|c|c|c|c|}
\hline \multirow[b]{2}{*}{ Item } & \multicolumn{3}{|c|}{ Herd } \\
\hline & 1 & 2 & 3 \\
\hline \multicolumn{4}{|l|}{ Cows (no.) } \\
\hline Total herd size & 329 & 740 & 627 \\
\hline Enrolled & 137 & 527 & 284 \\
\hline High-starch group & 72 & 260 & 139 \\
\hline Low-starch group & 65 & 267 & 146 \\
\hline Farm area (ha) & 73 & 250 & 157 \\
\hline Stocking rate (cows/ha) & 4.5 & 3.0 & 4.0 \\
\hline \multicolumn{4}{|l|}{ Breeding } \\
\hline Planned start of calving & Aug. 1 & Jul. 25 & Jul. 12 \\
\hline Start breeding & Oct. 20 & Oct. 16 & Sep. 30 \\
\hline End breeding & Dec. 28 & Jan. 5 & Dec. 20 \\
\hline Length (d) & 69 & 81 & 81 \\
\hline \multicolumn{4}{|l|}{ Feed treatment period } \\
\hline Start & Aug. 7 & Jul. 29 & Jul. 23 \\
\hline End & Sep. 19 & Sep. 14 & Aug. 30 \\
\hline Duration (d) & 43 & 47 & 38 \\
\hline
\end{tabular}


ensure that feeding levels consistent with farm policy were achieved while also allowing for a 10 to $15 \%$ difference in NSC between the high-starch and low-starch treatment groups during the first 6 wk of lactation.

The basal diet was temperate pasture comprising primarily perennial ryegrass (Lolium perenne L.) and white clover (Trifolium repens), and cows were provided with additional feeds to increase their DMI. The daily ration for each herd is presented in Table 3 . A weekly assessment of pasture DMI was performed using the rising plate meter (Farmworks, Palmerston North, New Zealand) technique previously described by Roche et al. (2005). This involved assessment of pre- and postgrazed pasture mass. The average DMI of pasture consumed per animal was calculated as the difference between the pre- and postgrazed pasture mass, multiplied by the area offered (hectares), and divided by the number of cows in the group; this was then adjusted for the duration of grazing (i.e., 12 or $24 \mathrm{~h}$ on the pasture). As animals were fed as a group, DMI is the estimate for the average animal in the population, and no individual cow intakes could be calculated. Pasture samples were collected for analysis of nutrient composition approximately every 2 wk by taking a minimum of 20 cuts to $5 \mathrm{~cm}$ above the ground at 5 - $\mathrm{m}$ intervals across the paddock and submitted for analysis. Where fed, the mass of silage was estimated from the wet weight fed and corrected for the DM percentage. Core samples were collected from the silage stack for feed composition analysis on 1 occasion.

The accuracy of the mass of supplementary feeds supplied via the in-parlor feeding system was assessed weekly. To do this, 10 individual feeders were selected at random and the mass of feed delivered was measured. The mass of feed was weighed to the nearest 0.1 $\mathrm{kg}$. Samples of the treatment feeds were collected at commencement of the treatment period for nutritional analysis. These analyses were undertaken using nearinfrared reflectance spectroscopy (Corson et al., 1999) at Hills Laboratory (Hamilton, New Zealand) and

Table 2. Breed distribution and mean (SD) age, calving date, and duration of feeding treatment for cows assigned to a diet designed to be high or low in NSC during the first 4 to 5 wk of lactation

\begin{tabular}{lcc}
\hline Item & High starch & Low starch \\
\hline Breed (no. of cows) & & \\
$>11 / 16$ th Holstein-Friesian & 110 & 123 \\
Crossbred & 329 & 332 \\
$>11 / 16$ th Jersey & 28 & 26 \\
Total & 467 & 481 \\
Age (yr) & $4.7(2.5)$ & $4.8(2.6)$ \\
Calving date & Aug. $10(10.9)$ & Aug. $11(10.9)$ \\
Treatment duration $(\mathrm{d})$ & $31.4(9.4)$ & $31.0(9.0)$ \\
\hline
\end{tabular}

Cumberland Valley Analytical Services (Hagerstown, $\mathrm{MD})$.

\section{Experimental Diets}

Herds 1, 2, and 3 offered cows supplements in addition to pasture (Table 3) to establish their base ration. In all herds, the high-starch diet was achieved by supplementing cows with 4 to $4.5 \mathrm{~kg}$ of DM of a mix of $75 \%$ cracked maize grain and $25 \%$ barley grain (Table 3 ). On 2 of the 3 farms (herds 1 and 3), the low-starch groups were fed $5.0 \mathrm{~kg}$ of DM of a supplement mix containing equal amounts of soybean hulls and palm kernel meal. In herd 2, the low-starch group was fed pasture and pasture silage only.

Because of the nature of the effect of the imposed diets on the ruminal fermentation of carbohydrate and protein, the amount of MP reaching the small intestine could not be determined from the current experimental design. However, it was possible to model the effect of diet on energy and protein balance using the Cornell Net Protein and Carbohydrate System (CNCPS; Fox et al., 1992). Kolver et al. (1998) and Higgs et al. (2013) evaluated the CNCPS for pasture-based systems and concluded that it was effective at modeling microbial protein flows and whole-body nitrogen and energy balance, thereby providing an effective means of predicting energy and protein balance in pasture-fed cows. The CNCPS-predicted diet composition (including ME) is presented in Table 3. The model confirms the adequacy of the diets relative to ME and MP requirements (Table $3)$.

\section{Transition Management of the Experimental Diets}

In herds 1 and 3, cows assigned to the high-starch and low-starch treatments received $1 \mathrm{~kg}$ of their respective supplements on the day of calving followed by daily increases of approximately $0.5 \mathrm{~kg}$ to a maximum of 5.5 $\mathrm{kg} /$ cow per day by $10 \mathrm{~d}$ postpartum. At approximately $35 \mathrm{~d}$ before the planned start of mating (PSM) date, the high-starch diet supplement was removed at a rate of $1 \mathrm{~kg} / \mathrm{d}$ and replaced with the same amount of the low-starch ration type. Thereafter, all cows were fed the same quantity of the low-starch ration, the amount depending on pasture availability.

In herd 2, cows assigned to the high-starch group were offered $0.25 \mathrm{~kg}$ on the day of calving followed by daily increases of approximately $0.20 \mathrm{~kg}$ to a maximum of $4.5 \mathrm{~kg} / \mathrm{cow}$ per day. At approximately $35 \mathrm{~d}$ before the PSM, the high-starch supplement was removed at a rate of $1 \mathrm{~kg} /$ cow per day, such that no in-parlor supplement was being fed during the month before the PSM to any of the cows in this herd. The low-starch group 
in this herd was fed pasture and pasture silage only throughout the study, with high-starch cows having equal access to these feeds.

The rationale for changing the rations before the start of the breeding programs was that the studies of Gong et al. (2002) and Garnsworthy et al. (2009) reported greater conception rates and a higher proportion of cows pregnant by $120 \mathrm{~d}$ postcalving when cows consumed a high-NSC diet from calving to first ovulation and a low-NSC diet subsequently. Diets high in starch $(>18 \%)$ and low in fat $(<4 \%)$ fed between 40 and 70 DIM were associated with a lower increase in plasma progesterone postovulation, providing a potential mechanism by which high-starch diets may negatively affect conception rates (Garnsworthy et al., 2008). Thus, high-starch diets fed during breeding appear to be deleterious to conception rates; for this reason the diet NSC content was reduced before the breeding period in the current study commenced.

\section{Resumption of Estrus}

Resumption of behavioral estrus was monitored in a randomly selected subset of 288 cows across each of the 3 herds, with 102, 88, and 98 cows in herds 1, 2, and 3, respectively. Resumption of behavioral estrus was assessed by visual determination of tail paint removal at wk 3, 4, 5, and 6 postcalving. At each inspection, the percentage of tail paint removed was recorded as 0,25 , 50,75 , or $100 \%$. Estrus was defined as having occurred when $\geq 25 \%$ of the tail paint was removed. Thus, the precision with which the interval from calving to first estrus could be determined was weekly.

\section{Determination of Plasma BHB, Plasma Fatty Acids, and Liver Triacylglycerol}

Plasma concentrations of BHB and fatty acids (FA) were determined at $14 \pm 3 \mathrm{~d}$ postpartum in this same

Table 3. Offered total daily DMI per cow, ration ingredient inclusion rates (based on DM offered), and predicted ration composition (based on offered DMI $)^{1}$

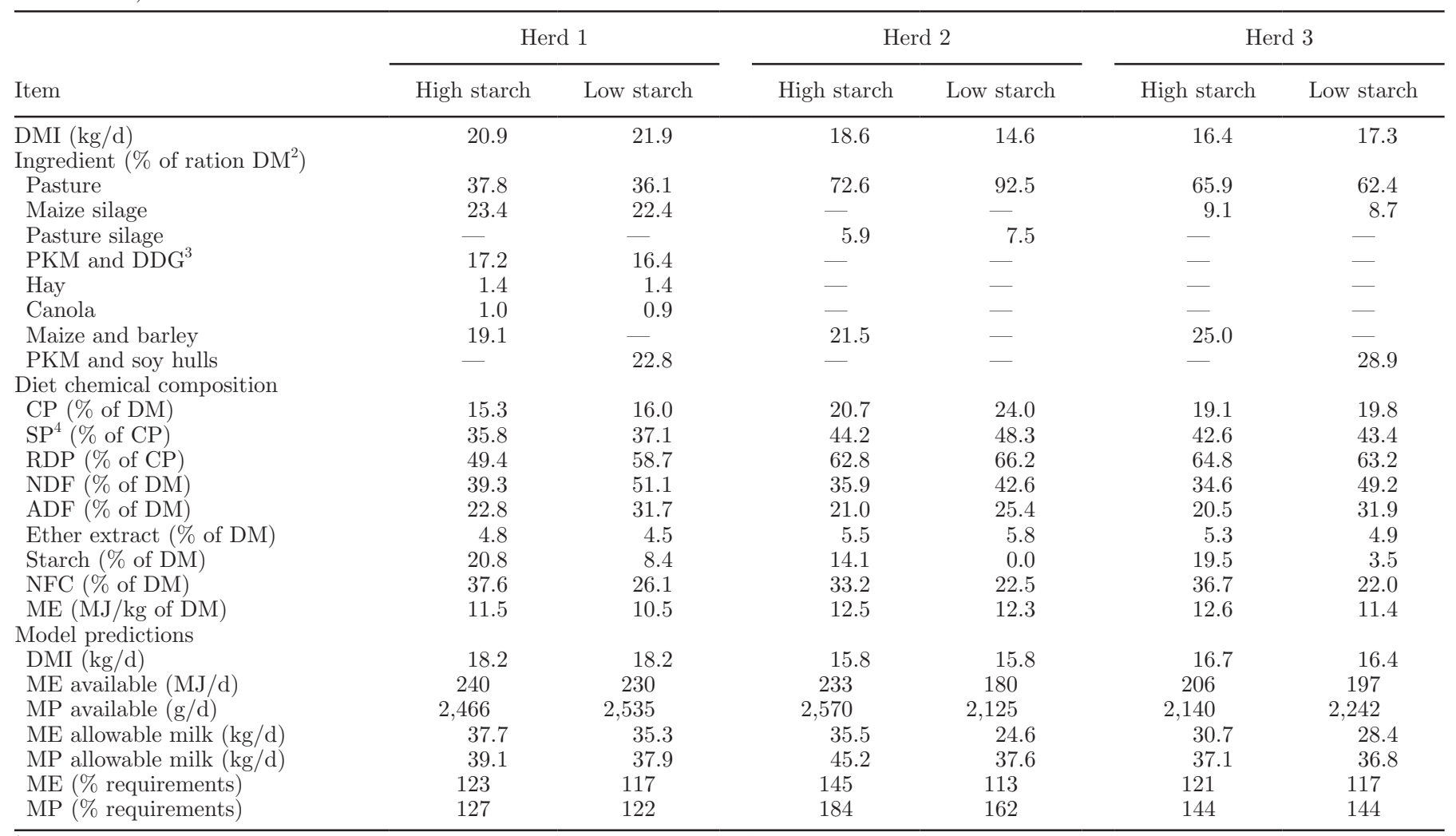

${ }^{1}$ Predictions for DMI and the potential milk that could be produced from the predicted supply of ME and MP were derived from model simulations. The composition and nutritional adequacy of the diets were modeled using the Cornell Net Carbohydrate and Protein System (Fox et al., 1992). Diets were formulated to be either high or low in NSC during the first 4 to $5 \mathrm{wk}$ of lactation. The experiment was undertaken on 3 commercial dairy herds in the Waikato region of New Zealand.

${ }^{2}$ Pasture silage was the result of ensiling perennial ryegrass- and white clover-dominant temperate pastures the spring before the experiment presented.

${ }^{3} \mathrm{PKM}=$ palm kernel meal; DDG $=$ dried distillers grain.

${ }^{4} \mathrm{SP}=$ soluble protein. 
subset of 288 cows. Blood samples were taken from the coccygeal vessels into evacuated tubes containing lithium heparin as an anticoagulant. Plasma was harvested and stored at $-20^{\circ} \mathrm{C}$ following centrifugation at 1,500 $\times g$ for $15 \mathrm{~min}$. Concentrations of BHB were determined using a validated cow-side test (Precision Xtra, Abbott, Columbus, OH; Iwersen et al., 2009). Moderate and elevated BHB concentrations were defined as $>1.2$ and $>3.0 \mathrm{mmol} / \mathrm{L}$, respectively. Concentrations of plasma FA were determined by New Zealand Veterinary Pathology (Palmerston North, New Zealand) using a commercially available kit (Wako Diagnostics, Mountain View, CA). Plasma FA of $>0.6 \mathrm{mmol} / \mathrm{L}$ were defined as high, as concentrations above this level are associated with an increased risk of postpartum disease (Ospina et al., 2013).

Liver biopsies were performed on a randomly selected group of 7 cows from each dietary treatment within each herd at d $14(\mathrm{SD}=2.0$; range $=11-17 \mathrm{~d}$; wk 2$)$, $24(\mathrm{SD}=4.7$; range $=18-31$; wk 3$)$, and $29(\mathrm{SD}=$ 3.0 ; range $=25-34$; wk 4). In total, 114 liver biopsy samples were successfully collected as the veterinarians were unable to get samples from cows on 12 occasions. Liver triacylglyceride (TAG) concentrations (\% of wet weight) were determined by Gribbles Veterinary Pathology (Dunedin, New Zealand) using a Roche modular analyzer (Roche Diagnostics, Basel, Switzerland). This determination followed overnight digestion with $20 \%$ potassium hydroxide solution, addition of $\mathrm{H}_{2} \mathrm{SO}_{4}$ to neutralize the potassium hydroxide, and addition of 3 -[(3-cholamidopropyl) dimethylammonio]-1-propanesulfonate to solubilize the triglycerides. Coefficients of variation were 1.7 and $1.8 \%$ for internal controls with means of 0.7 and $2.6 \mathrm{mmol} / \mathrm{L}$, respectively. The TAG concentrations were categorized as 1 to $5 \%, 5$ to $10 \%$, or $>10 \%$, respectively, which have been defined as mild, moderate, or severe fatty liver, respectively (Bobe et al., 2004).

\section{Body Condition and Reproductive Tract Health}

Body condition score (on a 1-10 scale; Roche et al., 2004) and vaginal discharge score were measured in 870 animals at $28 \pm 3 \mathrm{~d}$ postpartum by a single operator. Body condition score was assessed visually and by palpating the key areas that define the condition of the animal such as the backbone, long ribs, short ribs, hip bones, pin bones, and tail head. Assessment always occurred on the right side of the animal to avoid rumen deception.

Vaginal discharge score, a proxy for reproductive tract inflammation, was assessed using the Metricheck device (Simcro Tech, Hamilton, New Zealand) and the 5 -point scoring system described by McDougall et al.
(2007). The vulva of all animals was cleaned with a disposable paper towel and the device was inserted into the vagina, advanced to the anterior end, and then gently extracted, and any material present in the device was scored.

Two of the farms (herds 1 and 2) had automated walk-over weighing systems, and all farms had in-line milk yield meters (Metatron, GEA, Hamilton, New Zealand). These data were recovered from the on-farm database systems. It was not possible to acquire samples for milk composition analysis.

\section{Breeding Management}

The estrus detection system used during breeding varied among herds but was consistent within a herd. Predominantly, herd 1 relied on neck-mounted activity monitors (GEA), herd 2 relied on tail headmounted devices (LIC, Hamilton, New Zealand), and herd 3 relied on tail paint and visual observation. For the activity monitors, estrus was defined as occurring when activity was $>1.5 \mathrm{SD}$ above the average activity in the same 2 -h time period in the preceding $10 \mathrm{~d}$ for 3 sequential 2-h blocks.

Artificial insemination of lactating cows occurred following detection of estrus for 24 and $39 \mathrm{~d}$ for herds 1 and 3 , respectively, after which bulls were comingled with the herds for 42 and $45 \mathrm{~d}$, respectively. Herd 2 relied on AI for the entire 81-d breeding period.

Pregnancy testing occurred at $81 \mathrm{~d}(\mathrm{SD}=17$; range $=63-98 \mathrm{~d}$ ) after PSM. Those cows not defined as pregnant at this examination were retested at $122 \mathrm{~d}(\mathrm{SD}=$ 12 ; range $=112-135)$ after the PSM. At each examination, transrectal real-time ultrasonography was used to determine whether a cow was pregnant and, where pregnant, to estimate conception date. Where the estimated conception date was within $7 \mathrm{~d}$ of a recorded AI or natural breeding date (where recorded), the recorded date was accepted as the date of conception; otherwise, the veterinarian's estimate of conception date was accepted.

\section{Statistical Analyses}

Data analyses were undertaken using SAS version 9.3 (SAS Institute Inc., Cary, NC), SPSS version 21.0 (IBM SPSS Statistics for Windows, Armonk, NY), or Stata 14.1 (Stata Corp LP, College Station, TX). Data were checked for normality. A logarithmic transformation was used to normalize the distribution of BHB; backtransformed least squares means and 95\% confidence intervals are reported.

The noncategorized BHB and FA data were analyzed using mixed models (PROC MIXED). Ordinal data 
(vaginal discharge score and BCS) were analyzed using generalized mixed models (GLIMMIX). All models included the fixed effects of treatment, breed, parity, herd, and their 2-way interactions, and cow was included as a random effect. Nonsignificant interactions $(P>0.05)$ were removed from the final statistical model. Least squares means were calculated from the final models. Multiple comparison testing was adjusted for using the Tukey or Bonferroni adjustments.

The key reproductive outcomes were 3 -wk submission rate (i.e., proportion of cows inseminated within 3 wk after PSM), first service conception rate (i.e., proportion of cows pregnant to first insemination), 3- and 6 -wk pregnancy rate (i.e., proportion of cows confirmed pregnant by the end of the third or sixth week of the breeding period), and final nonpregnant rate (i.e., proportion of cows not pregnant at the end of the entire breeding period).

Multivariable logistic regression models with cow nested within herd were used to estimate the effect of treatment (i.e., high starch vs. low starch) for dichotomous reproductive outcome variables. Treatment, herd, and their interaction were included in each model as fixed effects. Associations with potential confounding variables, including age (categorized as 2,3 , and $>3$ yr), breed (categorized as Holstein-Friesian or Jersey if $>11 / 16$ th of either Holstein-Friesian or Jersey, respectively; all others categorized as crossbreds), DIM at PSM (categorized into 7-d blocks), and duration that a cow was supplemented with the treatment diets (categorized into $7 \mathrm{~d}$ blocks), were initially assessed using chi-squared analyses. Those found to be associated $(P$ $<0.2$ ) with the outcome variables were used in manual model building and included if the $P$-value was $<0.05$. Estimated marginal means and standard error of the mean were calculated for those variables present in the final models.

The interval data (i.e., calving to first observed estrus, PSM to first AI, and PSM to conception intervals) were modeled using survival analysis. Initially, bivariate associations between outcome variables and explanatory variables were assessed using Kaplan-Meier analysis, and those variables associated $(P<0.2)$ were offered to a Cox's proportional hazards model with herd as the frailty term. Herd $\times$ treatment interaction was included in each model. To assess whether the proportional hazards assumptions had been violated, a log-log plot was constructed and the Schoenfeld residuals were tested.

Cow BW (from 2 herds) and milk yield data were initially averaged daily (i.e., across a.m. and p.m. measurements); these daily data were then averaged across each week. Data for the first 12 wk of lactation were analyzed. Initially, bivariate analysis of average weekly BW and milk yields was undertaken using 1-way ANOVA with herd, age category, breed category, weeks in milk, and treatment as fixed effects. All of these variables (except treatment) were significant at the bivariate level. A generalized linear model was then constructed with weeks in milk as a repeated measure within cow using a first-order autoregressive correlation structure; the main effects previously identified were included in the model. Treatment was forced into the model by design. First-order interactions of treatment with other main effects were assessed and included when significant (i.e., $P<0.05$ ).

\section{Power Calculations}

A priori, a sample size of 400 cows/treatment group was calculated on the assumptions that we wished to detect a $9 \%$ difference in 6 -wk pregnancy rate between dietary treatment with $80 \%$ power and at $P<0.05$. Other assumptions were that the control group would have a 6 -wk pregnancy rate of $65 \%$ (the national median; Brownlie et al., 2014) and that 2-sided hypothesis testing would be undertaken. Sufficient cows were enrolled to detect such a difference if it were present. Subsets of cows were used for some of the secondary outcome variables. For example, 288 cows were assessed for calving to first estrus interval based on weekly assessment of removal of tail paint. Were the true difference in interval actually $5 \mathrm{~d}$, and if the standard deviation was assumed to be $12 \mathrm{~d}$ (based on the data of Burke et al., 2010), then between 90 and 100 cows per treatment group would have been required to find such a difference with $80 \%$ power and at $P<0.05$. As 288 cows in total were enrolled to assess this outcome, sufficient cows were enrolled to find such a difference, if it existed.

\section{RESULTS}

Estimated NFC content of the diets as modeled through the CNCPS (Fox et al., 1992) were 26.1, 22.5, and $22.0 \%$ for the low-starch treatments and 37.6, 33.2, and $36.7 \%$ for the high-starch treatments on herds 1,2 , and 3 , respectively (Table 3 ).

\section{Reproductive Tract Health Status}

There was no effect $(P=0.39)$ of treatment on vaginal discharge scores (1.5 vs. 1.4 for high-starch and low-starch groups, respectively; Figure 1) at $28 \pm$ 3 d postpartum. Herd 3 (1.9) recorded a greater $(P$ $<0.001)$ mean score compared with herd 1 (1.3; $P<$ $0.001)$ and herd 2 (1.5). There was no effect of breed $(P=0.8)$, but there was a treatment $\times$ breed interaction $(P=0.02)$, with Jersey cows in the low-starch 


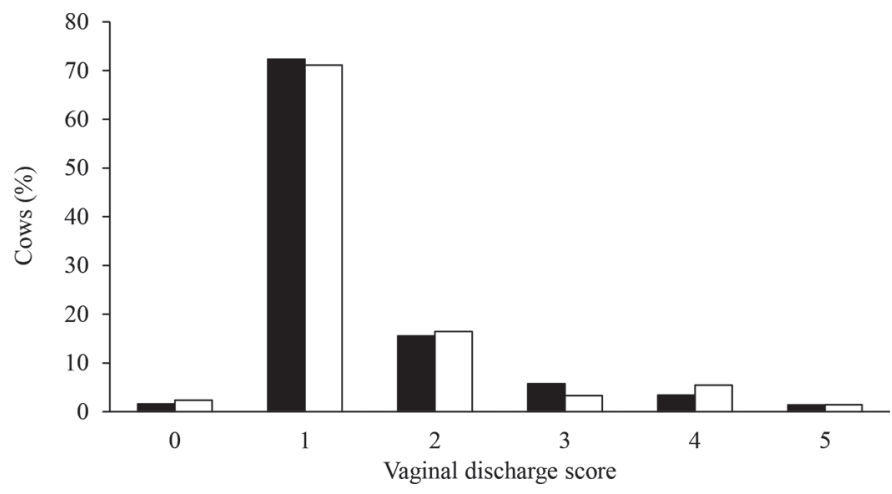

Figure 1. Frequency distribution of vaginal discharge scores for cows assigned to a diet containing high (open bar) or low (closed bar) NSC during the first 4 to $5 \mathrm{wk}$ of lactation. There was no significant difference between treatments for vaginal discharge scores $(P=0.30)$.

group having a greater mean vaginal discharge score compared with those in the high-starch group (1.7 vs. 1.2 , respectively). There were no other interactions detected.

\section{Reproduction}

The interval to first observed estrus was unaffected by treatment ( 33 vs. $34 \pm 2 \mathrm{~d}$ for high starch and low starch, respectively; $P=0.83$ ). The hazard of being detected in estrus was not affected by treatment (Figure $2 ; P>0.1)$, but there were effects of herd $(P<0.001)$ and age $(P<0.01)$. The interval from calving to first observed estrus was greater $(P<0.01)$ in herds 1 (34.1 $\pm 2.4 \mathrm{~d})$ and $3(34.1 \pm 2.0 \mathrm{~d})$ than in herd $2(29.5 \pm 2.2$ d). Two-year-old cows displayed earlier signs of estrus compared with 3 -yr-old cows $(30.5 \pm 2.5$ vs. $34.5 \pm 2.3$ $\mathrm{d} ; P=0.003)$ and $>3$-yr-old cows $(32.7 \pm 1.7 \mathrm{~d} ; P=$ $0.06)$. Holstein-Friesian cows tended $(P=0.06)$ to have a longer interval from calving to first estrus than Jersey cows $(34.6 \pm 4.9$ vs. $30.3 \pm 2.8 \mathrm{~d}$, respectively). There were no interactions between treatment and the other fixed effects that were included in the model.

There were tendencies $(P<0.1)$ for an interaction of herd $\times$ treatment for proportion pregnant to first service and for pregnancy by $6 \mathrm{wk}$, and this was significant for proportion finally pregnant. This was due to the high-starch treatment resulting in a lower proportion of cows pregnant to first service, pregnant by $6 \mathrm{wk}$, and pregnant at the end of the breeding program for herd 1 but no effect of treatment in the other 2 herds (Table 4).

There was no effect of treatment on the interval from the start of the seasonal breeding program to first insemination, nor was there a herd $\times$ treatment interaction (Table 5). However, there was a herd $\times$ treatment interaction for the interval from the start of the seasonal breeding program to conception, whereby cows fed the high-starch diet had a reduced hazard of conception compared with the low-starch group in herd 1 but not the other 2 herds (Table 6 ). The proportional hazards assumption was not violated, as the Schoenfeld residuals test was not significant $(P=0.83)$

\section{BCS, BW, and Milk Yield}

There was no effect of treatment on mean BCS (4.3 vs. 4.2 for the high-starch and low-starch cows, respectively; $P=0.18$; Figure 3 ) at 28 DIM. The effects of herd and age were both significant (both $P<0.001$ ). Two-year-old cows had higher BCS than 3-yr-old cows $(4.42$ vs. $4.07 ; P<0.001)$ and $>3$-yr-old cows $(4.16 ; P$ $<0.001)$. None of the treatment $\times$ herd, treatment $\times$ breed, or treatment $\times$ age interactions were significant.

There was no difference between treatments in BW $(448.0 \pm 2.9$ vs. $449.4 \pm 3.0 \mathrm{~kg}$ for high-starch vs. lowstarch groups, respectively; $P=0.60$; Figure 4). Body weight was different between herds 1 and $2(473 \pm 4$ and $424 \pm 2 \mathrm{~kg}$ for herds 1 and 2, respectively; $P<$ $0.001)$, age categories $(406 \pm 4,442 \pm 4$, and $498 \pm 3$ $\mathrm{kg}$ for 2,3 , and $>3 \mathrm{yr}$, respectively; $P<0.001$ ), and breeds $(477 \pm 4,446 \pm 2$, and $424 \pm 5 \mathrm{~kg}$ for HolsteinFriesians, crossbreds, and Jerseys, respectively; $P<$ $0.001)$ and by week of lactation $(P<0.001)$. There were no interactions between treatment and other main effects (all $P>0.3$ ).

Milk volume tended $(P=0.08)$ to be greater in the high-starch group than in the low-starch group $(22.3 \pm$ 0.22 vs. $21.9 \pm 0.22 \mathrm{~L} /$ cow per day for high starch vs. low starch, respectively; Figure 5). Yield varied among herds $(26.2 \pm 0.32,17.8 \pm 0.20$, and $22.2 \pm 0.24 \mathrm{~L} /$ cow per day for herds 1,2 , and 3 , respectively; $P<0.001$ ),

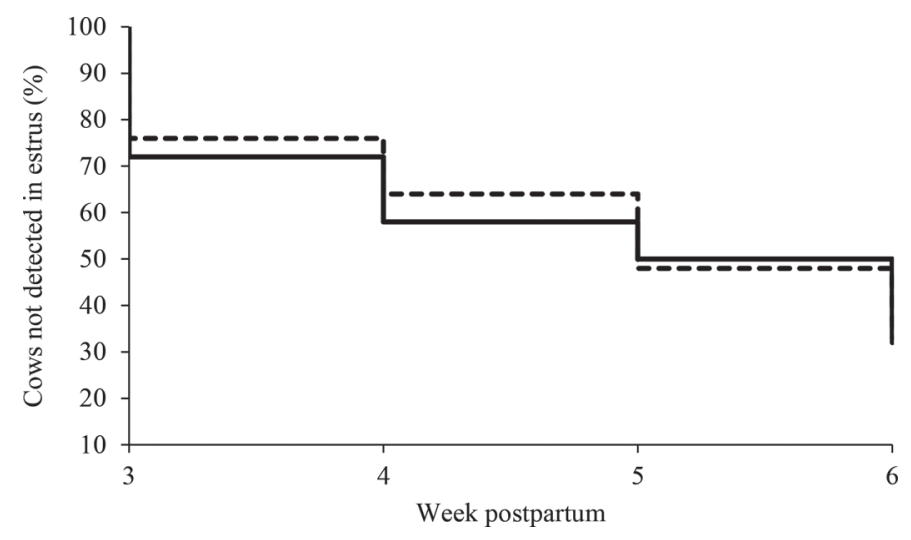

Figure 2. Cumulative survival for cows assigned to a diet containing high (dashed line) or low (solid line) NSC during the first 4 to $5 \mathrm{wk}$ of lactation on the interval between calving and first detected estrus. 
Table 4. The proportion of cows submitted for AI in the first 3 wk after the commencement of the seasonal breeding program, conceiving to first AI, pregnant after 3 or $6 \mathrm{wk}$, and pregnant by the end of a seasonal breeding period for cows assigned to a diet designed to be high or low in NSC during the first 4 to 5 wk of lactation

\begin{tabular}{|c|c|c|c|c|c|c|c|c|c|c|}
\hline Variable & Herd & \multicolumn{2}{|c|}{ High starch } & \multicolumn{2}{|c|}{ Low starch } & \multicolumn{5}{|c|}{$P$-value } \\
\hline \multirow[t]{2}{*}{$\overline{\mathrm{SubD} 21^{2}}$} & 1 & 0.79 & 0.06 & 0.89 & 0.07 & 0.216 & 0.658 & 0.137 & 0.004 & 0.001 \\
\hline & 3 & 0.86 & 0.05 & 0.82 & 0.04 & & & & & \\
\hline \multirow[t]{2}{*}{$\mathrm{ConS}^{3}{ }^{3}$} & 1 & $0.43^{\mathrm{b}}$ & 0.50 & $0.61^{\mathrm{a}}$ & 0.79 & 0.238 & 0.059 & 0.078 & & 0.025 \\
\hline & 2 & 0.65 & 1.07 & 0.61 & 0.80 & & & & & \\
\hline Preg $3 w^{4}$ & 3 & 0.52 & 0.07 & 0.52 & 0.07 & & & & & \\
\hline \multirow[t]{3}{*}{ Preg $6 w^{5}{ }^{5}$} & 1 & $0.67^{\mathrm{b}}$ & 0.06 & $0.85^{\mathrm{a}}$ & 0.05 & 0.043 & 0.369 & 0.058 & 0.003 & 0.002 \\
\hline & 2 & 0.82 & 0.03 & 0.81 & 0.03 & & & & & \\
\hline & 3 & 0.77 & 0.04 & 0.80 & 0.04 & & & & & \\
\hline \multirow[t]{2}{*}{ Final preg ${ }^{6}$} & 1 & $0.85^{\mathrm{b}}$ & 0.05 & $0.97^{\mathrm{a}}$ & 0.03 & 0.174 & 0.094 & 0.026 & 0.002 & 0.024 \\
\hline & 2 & 0.95 & 0.05 & 0.93 & 0.04 & & & & & \\
\hline
\end{tabular}

\footnotetext{
${ }^{\mathrm{a}, \mathrm{b}}$ Means within variable and herd with different superscripts differ at $P<0.05$.

${ }^{1}$ Interval (d) from calving to the start of the seasonal breeding program (PSM).

${ }^{2}$ Submission to AI in the first 3 wk of the breeding period.

${ }^{3}$ Conception to first AI.

${ }^{4}$ Proportion of cows pregnant in the first 3 wk of the breeding period.

${ }^{5}$ Proportion of cows pregnant in the first 6 wk of the breeding period.

${ }^{6}$ Proportion of cows pregnant by the end of the breeding period.
}

ages $(17.7 \pm 0.27,22.3 \pm 0.28$, and $26.3 \pm 0.20 \mathrm{~L} / \mathrm{cow}$ per day for 2,3 , and $>3 \mathrm{yr}$, respectively; $P<0.001$ ), and breeds $(24.1 \pm 0.24,22.5 \pm 0.14$, and $19.7 \pm 0.44$ $\mathrm{L} /$ cow per day for Friesians, crossbreds, and Jerseys, respectively; $P<0.001)$ and by week of lactation $(P<$ 0.001). There were no first-order interactions between treatment and the other main effects (all $P>0.1$ ).

\section{Plasma BHB, FA, and Liver TAG}

The effects of treatment, breed, and parity on plasma $\mathrm{BHB}$ concentrations and the prevalence of cows with moderate and elevated BHB concentrations are sum- marized in Table 6 . There was a treatment $\times$ herd interaction $(P<0.001)$, whereby high-starch cows in herd 2 had lower BHB concentrations than low-starch cows; however, treatment had no effect in herds 1 and 3 (herd 1: 0.90 vs. $1.03 \mathrm{mmol} / \mathrm{L}, 95 \% \mathrm{CI}=0.79-1.03$ and 0.89-1.19 mmol/L; herd 2: 0.79 vs. $1.45 \mathrm{mmol} / \mathrm{L}, 95 \%$ $\mathrm{CI}=0.67-0.92$ and $1.23-1.71 \mathrm{mmol} / \mathrm{L}$; and herd 3: 0.69 vs. $0.92 \mathrm{mmol} / \mathrm{L}, 95 \% \mathrm{CI}=0.59-0.80$ and $0.79-1.06$ $\mathrm{mmol} / \mathrm{L}$ for high-starch and low-starch groups, respectively). There were no interactions between treatment and any other effects in the model. Cows with an elevated BHB concentration at 14 DIM tended $(P=$ $0.08)$ to be less likely to be inseminated in the first $3 \mathrm{wk}$

Table 5. The hazard ratio and SEM for the planned start of mating (PSM) to first estrus (PSM S1) and planned start of mating date to conception intervals (PSM con) for cows supplemented with a high-NSC diet or a low-NSC diet postpartum

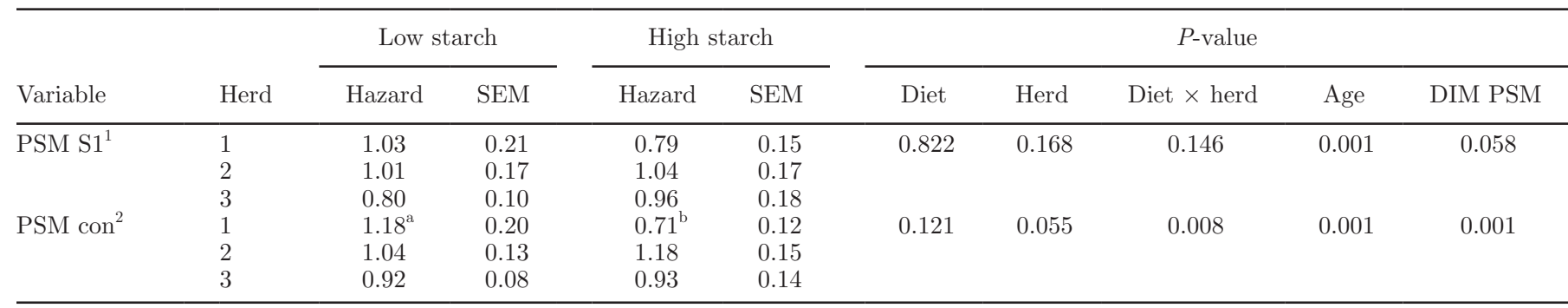

\footnotetext{
a,b Hazard ratios by treatment (diet) within herd with different superscripts differ at $P<0.05$. The $P$-values are from Cox's proportional hazards survival models.

${ }^{1}$ Interval (d) from the PSM to first AI.

${ }^{2}$ Interval (d) from the PSM to conception.
} 


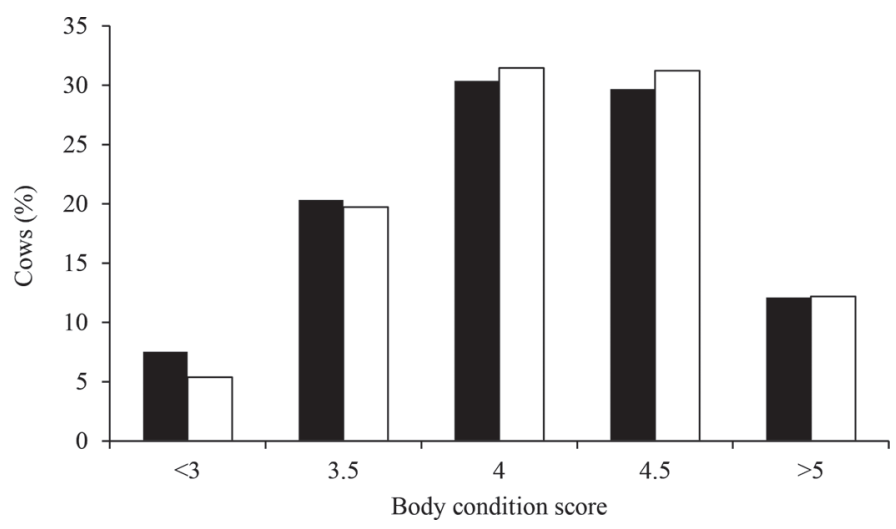

Figure 3. Frequency distribution of BCS of cows assigned to a diet containing high (open bar) or low (closed bar) NSC during the first 4 to 5 wk of lactation. Body condition score was unaffected by treatments $(P=0.18)$.

of the seasonal breeding period $(0.84 \pm 0.01$ vs. $0.90 \pm$ 0.02 for elevated-BHB vs. low-BHB cows, respectively). The mean interval from PSM to first AI was $3 \mathrm{~d}$ longer $(P=0.05)$ in elevated-BHB cows $(15.5 \mathrm{~d} ; 95 \% \mathrm{CI}=$ 12.6-18.4 d) compared with low-BHB cows (12.5 d; $95 \% \mathrm{CI}=10.9-14.0 \mathrm{~d})$. Cows with elevated BHB were less likely to conceive to first insemination $(0.48 \pm 0.07$ vs. $0.55 \pm 0.07$ for elevated-BHB vs. low-BHB cows, respectively; $P<0.001)$ and to be pregnant in the first 3 wk of the seasonal breeding period $(0.45 \pm 0.01$ vs. 0.55 \pm 0.02 for elevated-BHB vs. low-BHB cows, respec-

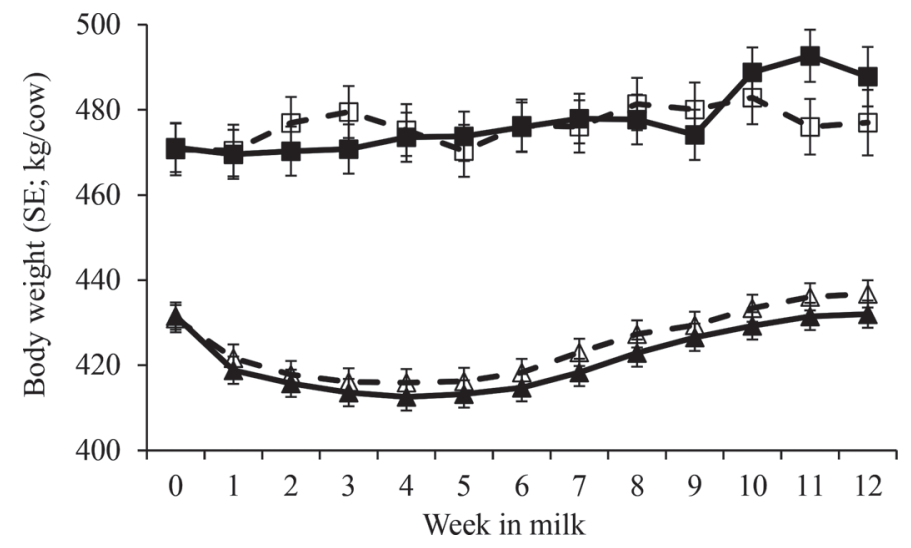

Figure 4. Mean (SE) BW ( $\mathrm{kg} / \mathrm{cow})$ for cows assigned to a diet with high NSC (closed symbols and solid line) or low NSC (open symbols and dashed line) in herds 1 (squares) and 2 (triangles).

tively; $P<0.05)$. Blood BHB was not associated with proportion of cows pregnant by 6 wk into the breeding period $(0.73 \pm 0.10$ vs. $0.78 \pm 0.04$ for elevated-BHB vs. low-BHB cows, respectively; $P=0.32$ ) or with the mean interval from PSM to pregnancy $[30.2(95 \% \mathrm{CI}=$ $25.6-34.9)$ vs. $25.9(95 \% \mathrm{CI}=22.7-29.2)$ d from PSM to pregnancy for elevated-BHB vs. low-BHB cows, respectively; $P=0.20]$.

Plasma FA concentrations were lower $(P<0.001)$ in high-starch cows than in low-starch cows and varied $(P<0.05)$ among herds, breeds, and age (Table

Table 6. The effect (95\% CI in parentheses) of treatment, herd, breed, and parity on plasma concentrations of BHB and fatty acids (FA) and the incidence of subclinical and clinical ketosis for cows assigned to a diet designed to be high or low in NSC during the first 4 to 5 wk of lactation

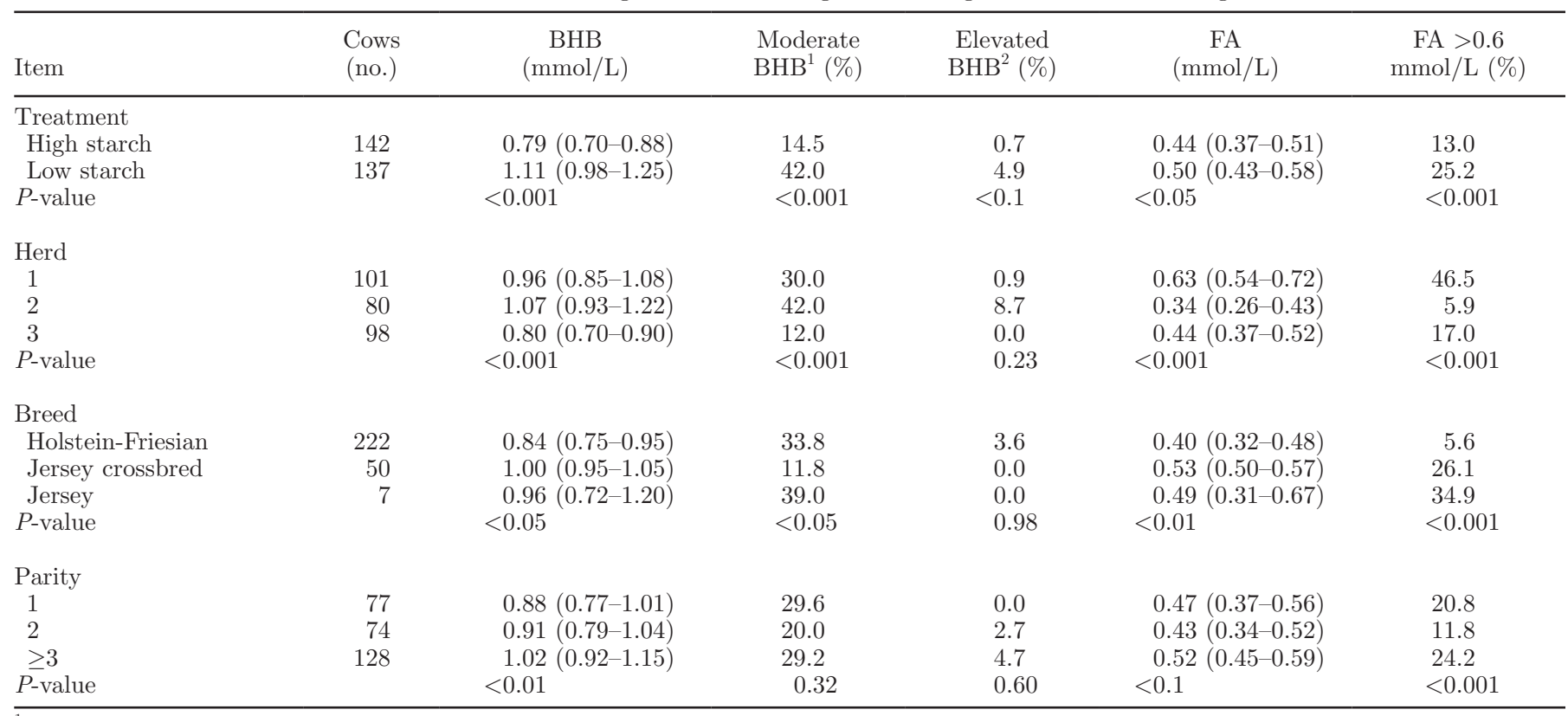

${ }^{1}$ Moderate BHB concentrations $>1.2 \mathrm{mmol} / \mathrm{L}$.

${ }^{2}$ Elevated $\mathrm{BHB}>3.0 \mathrm{mmol} / \mathrm{L}$. 


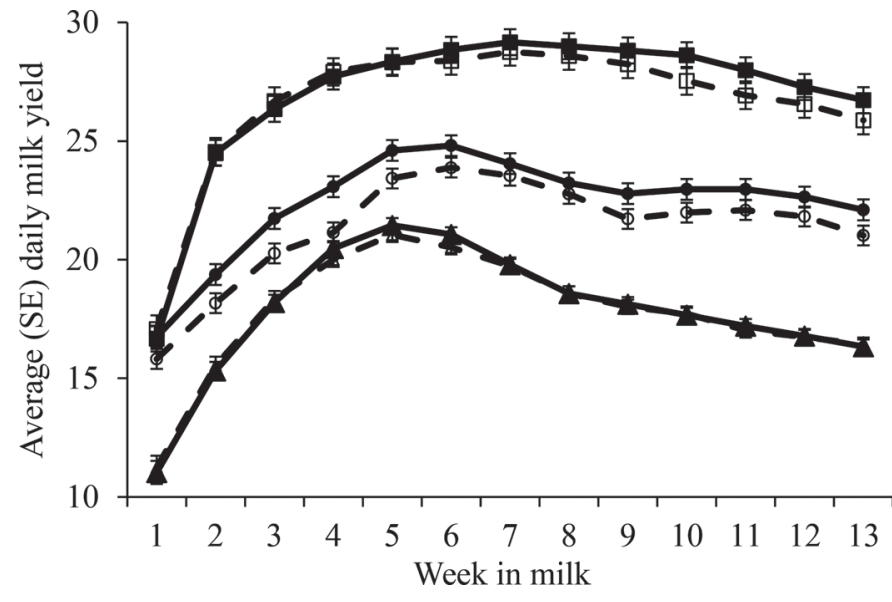

Figure 5. Mean (SE) daily milk yield (L/cow per day) measured by in-line meters across week for cows assigned to a diet containing high (closed symbols and solid line) or low (open symbols and dashed line) NSC for herds 1 (squares), 2 (triangles), and 3 (circles).

$6)$. There was a treatment $\times$ herd interaction $(P=$ 0.001) in which the percentage of cows with plasma FA $>0.6 \mathrm{mmol} / \mathrm{L}$ was lower in the high-starch group than in the low-starch group for herds 1 and 2 but not herd 3 (herd 1: 36.6 vs. $56.7 \%, 95 \%$ CI $=32.9-40.5 \%$ and $53.4-59.9 \%$; herd $2: 2.6 \%$ vs. $12.9 \%, 95 \% \mathrm{CI}=$ $2.2-3.1 \%$ and $10.8-15.3 \%$; and herd $3: 17.5$ vs. $16.5 \%$, $95 \% \mathrm{CI}=13.9-21.7 \%$ and $12.6-21.1 \%$ for the highstarch and low-starch groups, respectively). Elevated FA concentrations were not associated with conception to first breeding $(0.53 \pm 0.04$ vs. $0.58 \pm 0.03$ for cows with FA $>0.6$ vs. $\leq 0.6 \mathrm{mmol} / \mathrm{L}$, respectively; $P=0.42)$ or pregnancy by $3 \mathrm{wk}(0.49 \pm 0.05$ vs. $0.56 \pm 0.03$ for cows with FA $>0.6$ vs. $\leq 0.6 \mathrm{mmol} / \mathrm{L}$, respectively; $P=$ $0.38)$ or 6 wk after PSM $(0.76 \pm 0.03$ vs. $0.82 \pm 0.03$ for cows with $\mathrm{FA}>0.6$ vs. $\leq 0.6 \mathrm{mmol} / \mathrm{L}$, respectively; $P=0.29)$.

A total of $84(73.7 \%), 27(23.7 \%)$, and $3(2.6 \%)$ of the 114 liver samples had TAG concentrations defined as mild, moderate, or severe fatty liver, respectively. At the bivariate level, there was no effect of treatment on the proportion of liver samples in these categories $(P=0.12)$. Likewise, there was no treatment effect on $\log _{10}$ TAG concentrations $(P=0.11)$, but $\log _{10}$ TAG concentrations varied among herds $(P<0.001)$, breeds $(P<0.01)$, ages $(P=0.02)$, and week postpartum $(P$ $=0.04)$. There was a herd $\times$ treatment interaction $(P$ $=0.05$; Figure $6 \mathrm{a}$ ) in which the low-starch group was associated with a trend $(P<0.1)$ for higher TAG concentration in herd 2 but not in herds 1 and 3 . There was also a treatment $\times$ week postpartum interaction $(P$ $=0.04 ;$ Figure $6 \mathrm{~b}$ ) whereby TAG concentrations tended $(P<0.01)$ to be lower at wk 4 in the low-starch group compared with the high-starch group.

\section{DISCUSSION}

We designed this study to test the hypothesis that increasing dietary starch offered to grazing dairy cows in early lactation would improve reproductive performance by limiting BCS and BW loss and improving metabolic health. Biologically significant differences in diet NFC and NSC were established on all farms (Table 3), with between 10 and $15 \%$ differences in NFC estimated. There were tendencies for herd $\times$ treatment interactions for conception rate to first AI and proportion of cows pregnant in the first 6 wk of the breeding period, and there was a significant herd $\times$ treatment interaction for proportion of cows pregnant by the end of the breeding period. This was due to reduced pregnancy proportion to first AI and reduced proportions of cows pregnant in the first 6 wk and by the end of the breeding period in the high-starch compared with low-starch group in 1 herd but not in the other 2 herds. There was no effect of diet on cow BCS or early-lactation BW change and only a very small effect

(A)

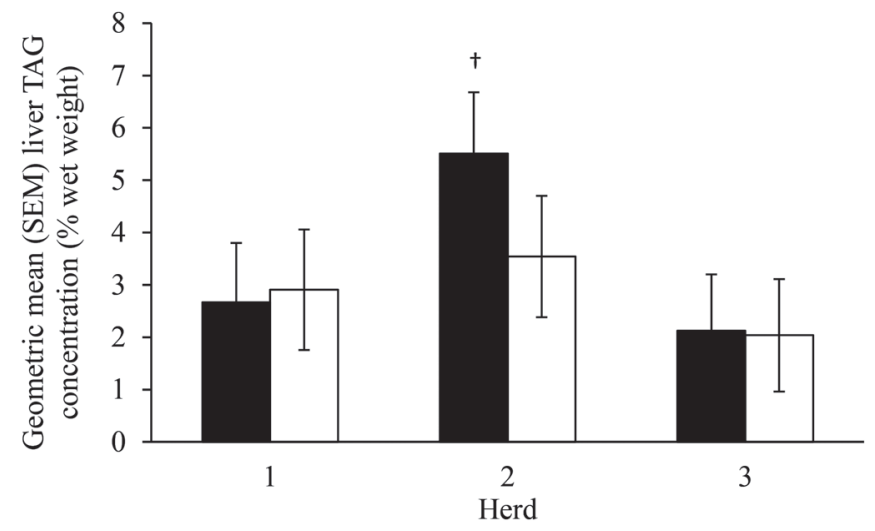

(B)

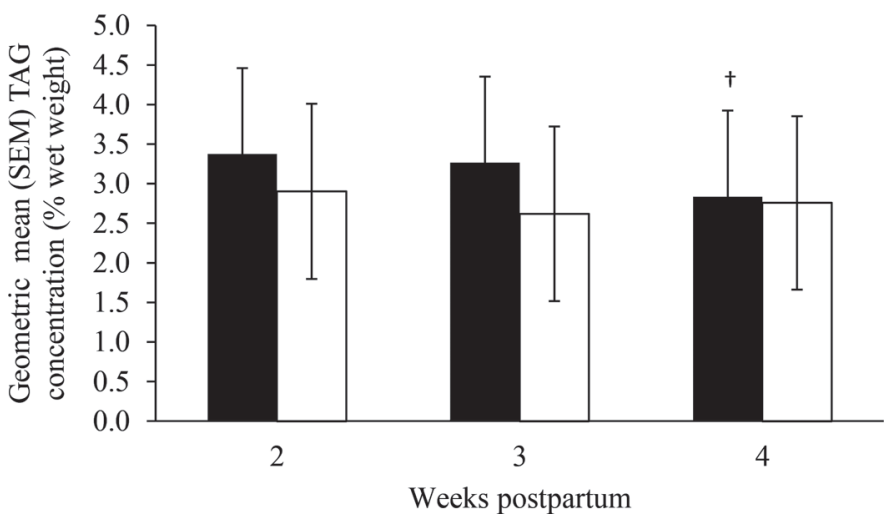

Figure 6. Geometric mean (SEM) concentrations of triacylglycerol (TAG) in the liver (\% of wet weight) by (A) herd and (B) week postpartum for cows assigned to a diet containing high (open bar) or low (closed bar) NSC during the first 4 to 5 wk of lactation. Dagger $(\dagger)$ indicates a difference of $P<0.1$ between herds $(\mathrm{A})$ or within $\operatorname{diet}(\mathrm{B})$. 
on daily milk yield. Increasing dietary starch reduced plasma BHB and FA concentrations, but the effects were not associated with improvements in reproduction and, at least in blood FA concentration, the recorded changes were biologically small. Furthermore, the effect was inconsistent, with herd $\times$ treatment interactions for both of these variables.

Collectively, the results indicate that the trial objective to alter the dietary starch of grazing dairy cows in early lactation was achieved. As cows from the 2 treatment groups were cograzed within farm, estimates of individual animal pasture DMI are not possible. Thus, no definite conclusions can be deduced as to whether, and to what degree, the substitution of supplement for pasture occurred (Bargo et al., 2003). The lack of effect of concentrate treatment in herds 1 and 3 on milk yield, $\mathrm{BW}$, or BCS indicate that cows likely reduced their intake of pasture ME by an equivalent amount in each of the dietary treatment groups; if so, this indicates that DM substitution was approximately $20 \%$ greater in the cows consuming the high-starch concentrate than in those consuming the low-starch concentrate. This has been reported previously (Bargo et al., 2003; Higgs et al., 2013) and is consistent with the suppressive effects of high-starch concentrates on plasma ghrelin concentrations relative to low-starch concentrates (Sheahan et al., 2013). Similarly, in herd 2, it would appear that cows reduced their ME intake from pasture and pasture silage (high-starch treatment) by an amount equivalent to the ME consumed as concentrate, as the treatment did not affect milk yield and effects on BW and BCS at this stage of lactation were very small (Roche et al., 2006). In other words, substitution of the high-starch concentrate for pasture was very high (90-100\%). If this is true, it means that the treatment difference in NSC is even greater than intended in herd 2, as the high-starch treatment consumed less pasture DM relative to that predicted (Table 3). Thus, it is possible that dietary treatments could have differently affected substitution rate; that is, pasture DMI may have been differentially affected by the different types of carbohydrates consumed in the concentrate supplements.

Due to the seasonal breeding program used, variation in dates of calving, and the desire to reduce the level of starch approximately 1 mo before the start of the seasonal breeding program, the period of feeding varied among animals. Thus, cows calving early in the seasonal calving program were exposed to the diet for a longer period of time than cows calving later in the seasonal calving period. This study design reflects the practicalities of feeding interventions on-farm. With seasonal breeding systems, all cows are eligible for breeding on the day that the breeding program commences, irrespective of their DIM. Thus, although optimal rations may be associated with DIM, in seasonal breeding programs calendar dates rather than DIM become the determinant of both feeding and breeding decisions.

The diets were designed to manipulate diet NSC and NFC concentrations relative to NDF. However, because of the applied nature of this study, there were also changes in other dietary components. Hence, the observed effects may be due, at least partly, to changes in other components of the diet. For example, due to the diet design, there were also effects on CP and MP intake, particularly in herd 2. An observational study in New Zealand suggested that higher ratios of dietary nitrogen to soluble carbohydrate were associated with higher milk urea, which in turn might negatively affect fertility (Moller et al., 1993). However, such an explanation appears unlikely for herds 1 and 3 as the $\mathrm{CP}$ and MP intakes varied relatively little between diets in these herds.

\section{Effects of Diet NSC Content on Reproductive Tract Health and Reproduction Outcomes}

There was no effect of diet on reproductive tract health status in the early postpartum period. Uterine infection can delay uterine involution, adversely affect follicular development, and delay postpartum resumption of estrous cyclicity (Sheldon et al., 2002; Galvão et al., 2010), and it has been reported that metabolic indicators of energy status are associated with uterine health (Hammon et al., 2006). Additionally, in New Zealand grazing systems, cows with elevated $(>1.2$ $\mathrm{mmol} / \mathrm{L}$ ) blood BHB concentrations at 5 DIM had a higher prevalence of uterine disease than cows with lower BHB concentrations at this time (24 vs. 8\%; Compton et al., 2015). In the current study, however, there was no dietary treatment effect on vaginal discharge score despite lower circulating $\mathrm{BHB}$ and FA concentrations in high-starch cows.

The failure of the high-starch diet to shorten the postpartum anestrous period and increase pregnancy rates is inconsistent with previous reports in grazing dairy cows (Burke et al., 2010) in which postpartum supplementation with cereal grains was associated with a shorter interval from calving to first ovulation, a larger proportion of cows submitted to first AI, and a greater proportion of cows pregnant by $6 \mathrm{wk}$. The reasons for the different treatment effects between these studies are not clear, but several potential differences in farm management, genetics, and study design may have contributed.

First, it is possible that the positive effects reported by Burke et al. (2010) were due to chance, with the experiment underpowered to precisely measure the effect of nutrition on reproduction. As the current experiment 
was designed specifically to determine the effect of diet NSC on reproduction variables, the presented results are more likely to reflect the true effect of diet. Second, the experiments differed in the degree of change in NSC that was achieved. On average, diet NSC (\% of DM) concentration was increased by 12 percentage points in the current study; this represented a relative increase of $54 \%$ in the high-starch diet. In comparison, Burke et al. (2010) achieved a 20 percentage point separation in diet NSC concentration in their experiment, which was a relative increase of $114 \%$ in diet NSC percentage. Hence, the current study achieved a smaller separation in diet NSC between the treatments than that of the earlier study; this may have contributed to the lack of a positive effect in this study. The experimental differences in diet NSC content are unlikely to be the primary contributory factor, however, as the positive effect of diet NSC on reproductive function was optimal at starch concentrations $>16 \%$ of DM but reportedly lost at $>23 \%$ of DM starch inclusion (Garnsworthy et al., 2008). Therefore, it is not clear why our results differ from those of Burke et al. (2010) in grazing dairy cows and those of Gong et al. (2002) and Garnsworthy et al. (2009); however, considering the scale of the experiment (i.e., multiple farms and almost 1,000 cows), our results more than likely best reflect the effect of increasing the NSC concentration of the diet consumed by grazing dairy cows in early lactation.

What is particularly interesting in this study, however, is the interactions between herd and dietary starch. Increased dietary starch in early lactation had a substantial negative effect on first service pregnancy rates and both 6-wk and final pregnancy rates in herd 1, but no effects in the other herds. The reasons for the deleterious effects of starch on conception and pregnancy rates in herd 1 are unclear. This herd was the highest yielding herd among those studied. At the end of the treatment period, cows were transitioned to a diet intermediate in starch over a 4-d period; this occurred approximately 1 mo before the PSM. Examination of daily milk yield records (data not presented) during this phase indicated a decline of 6 to $7 \%$ over this 4 - to 5 -d period followed by an increase within $5 \mathrm{~d}$ to a level exceeding the milk yield before the treatment diet was terminated. This change in the milk yield profile likely reflects the time necessary for a rumen adjustment to the change in diet NSC to NDF. Although such a small change is unlikely to significantly affect factors critical to reproductive success (e.g., oocyte or uterine function), it is possible that a perturbation in the cow's nutrition at this time was sufficient to negatively affect subsequent conception rates in this particular herd. However, this does not explain why such an effect was not evident in the other treatment groups. Neverthe- less, the results indicate either a lack of effect or a negative effect of increasing NSC content in the diet of grazing dairy cows in early lactation on reproductive variables.

\section{Effect of Treatment on Milk Yield and BW}

Milk volume tended to be increased in the high-starch treatment groups. This is consistent with the published literature, in which cows offered a diet with greater NFC content postpartum produced a greater milk volume, less milk fat, and more milk protein and lactose (Roche et al., 2010; Higgs et al., 2013). The tendency for increased volume is likely a result of an increase in circulating glucose associated with increased ruminal propionate production in the ruminal fermentation of NSC. Glucose is the sole precursor for the glucose and galactose moieties of lactose, and, as lactose is the major osmoregulator of milk yield, the availability of glucose for increased lactose production is probably the reason for the increased milk yield in high-starch cows. Unfortunately, we were unable to measure milk composition during the experiment on these commercial farms. We are, therefore, unable to confirm or reject our hypothesis to explain the increase in milk yield in the current study.

Body weight was not affected by treatment in the 2 herds assessed; this is consistent with previous studies, in which cows were supplemented postpartum with NSC (Roche et al., 2006, 2010) or a mixed concentrate feed (McCarthy et al., 2007), and BCS change was not affected during the first 4 to 5 wk of lactation. Although BW measurements ceased at 13 wk postpartum, cows consumed the same diet from approximately 35 DIM. The inability to alter the trajectory of BCS and $\mathrm{BW}$ loss in grazing cows by nutrition during the first 35 DIM (Roche et al., 2009) and the lack of difference in dietary starch content after 35 DIM in this study explain the lack of effect of NSC treatment on BW and BCS. Nonetheless, it is important that the previous results from controlled experimentation are validated in commercial farm settings. It can, therefore, be concluded that changes in the proportion of starch in the diet of grazing dairy cows in early lactation had no effect on cow BCS at 28 DIM or BW change during the first $5 \mathrm{wk}$ in milk.

\section{Indicators of Metabolic Status}

High-starch diets reduced the concentrations of FA and BHB in blood 2 wk postcalving, but the highstarch diet was not associated with an improvement in reproduction. The transition period is associated with the potential occurrence of multiple diseases that affect 
production, fertility, and health, and excess FA mobilization and hyperketonemia are often implicated (Drackley, 1999). The lower plasma BHB and FA concentrations in the cows assigned to the high-starch treatment would, therefore, potentially suggest a favorable effect of increased starch on metabolic status during early lactation. However, the effect on blood FA concentration is biologically small $(0.44$ vs. $0.50 \mathrm{mmol} / \mathrm{L}$ for the high- and low-starch diets, respectively). In fact, the difference in net release of FA from adipose tissue was so small that it did not register as a difference in either BCS or BW. Therefore, although statistically significant, the effect of treatment on blood FA concentration was of limited biological significance, as is indicated by the lack of a positive effect of high-starch treatments on either liver TAG or, ultimately, reproductive outcomes.

Elevated BHB is associated with negative energy balance in which the capacity of the liver to oxidize FA and store triacylglycerol is exceeded (Baird, 1982). Additionally, in grazing systems, blood BHB concentrations may be higher than would be expected in TMR systems because of the increased supply of BHB of ruminal origin and the lower yield of ruminal propionate. The increased blood BHB concentration in the low-starch treatment in this study is consistent with the report of Roche et al. (2010), who offered cows isoenergetic diets but with different NSC content. They reported that blood BHB concentration was $100 \%$ greater in the low-starch treatment compared with the high-starch treatment even though diet NSC content did not affect blood FA concentration or BCS loss. The reduction in blood BHB concentrations in high-starch cows was presumably a consequence of increased ruminal propionate production from the starch supplement. The increased supply of propionate facilitates greater gluconeogenesis and, therefore, increases the hepatic capacity to undertake the final stages of FA $\beta$-oxidation.

Analyses of the associations between FA, BHB, and reproductive performance, independent of dietary treatment, found that there was no association between FA and any measure of reproductive performance. Elevated BHB concentrations at 14 DIM were, however, associated with a longer interval from the PSM to first breeding, reduced conception rate to first insemination, and lower 3-wk pregnancy rate. This indicates that for individual cows in the population that were in excessive NEB, reproductive performance was compromised. As there was no favorable effect of treatment on reproduction, however, it may be concluded that although elevated BHB concentrations are deleterious to reproductive performance, feeding a high-starch diet does not ameliorate the effects of NEB on reproductive performance.

\section{CONCLUSIONS}

Supplementing grazing dairy cows with starch did not positively affect reproduction outcomes. In fact, there is evidence of a risk of reduced pregnancy rates when cows consumed the high-starch diet. Greater starch content in the diet reduced plasma BHB and FA concentrations at 14 DIM but did not alter BW or BCS and had only a small effect on milk production. The results indicate that some aspects of the farm system and feeding management affect the response to starch supplementation. Further studies with larger numbers of herds and more detailed measures of potentially influencing variables are required to understand what cow- and herd-level variables may affect the response to changes in ration starch concentration.

\section{ACKNOWLEDGMENTS}

We thank the herd owners and their staff for implementing the feeding system for this study. Elizabeth Blythe, Joanne Niethammer, and Cathy Yanez of Cognosco, AnexaFVC, Morrinsville, New Zealand, undertook the on-farm measurements and data collation. This work was funded by the Ministry of Business, Innovation and Employment (DRCX1302, Wellington, New Zealand) and New Zealand dairy farmers through DairyNZ Inc. (RD1404, Hamilton, New Zealand).

\section{REFERENCES}

Baird, G. D. 1982. Primary ketosis in the high-producing dairy cow: Clinical and subclinical disorders, treatment, prevention and outlook. J. Dairy Sci. 65:1-10.

Bargo, F., L. D. Muller, E. S. Kolver, and J. E. Delahoy. 2003. Production and digestion of supplemented dairy cows on pasture. J. Dairy Sci. 86:1-42.

Bauman, D. E., and W. B. Currie. 1980. Partitioning of nutrients during pregnancy and lactation: A review of mechanisms involving homeostasis and homeorhesis. J. Dairy Sci. 63:1514-1529.

Bell, A. W. 1995. Regulation of organic nutrient metabolism during transition from late pregnancy to early lactation. J. Anim. Sci. 73:2804-2819.

Bobe, G., J. W. Young, and D. C. Beitz. 2004. Invited review: Pathology, etiology, prevention, and treatment of fatty liver in dairy cows. J. Dairy Sci. 87:3105-3124.

Brownlie, T. S., J. M. Morton, C. Heuer, J. Hunnam, and S. McDougall. 2014. Reproductive performance of seasonal-calving, pasturebased dairy herds in four regions of New Zealand. N. Z. Vet. J. 62:77-86.

Buckley, F., K. O'Sullivan, J. F. Mee, R. D. Evans, and P. Dillon. 2003. Relationships among milk yield, body condition, cow weight, and reproduction in spring-calved Holstein-Friesians. J. Dairy Sci. $86: 2308-2319$.

Burke, C. R., J. K. Kay, C. V. C. Phyn, S. Meier, J. M. Lee, and J. R. Roche. 2010. Effects of dietary nonstructural carbohydrates preand postpartum on reproduction of grazing dairy cows. J. Dairy Sci. 93:4292-4296.

Burke, C. R., and J. R. Roche. 2007. Effects of pasture feeding during the periparturient period on postpartum anovulation in grazed dairy cows. J. Dairy Sci. 90:4304-4312. 
Compton, C. W., L. Young, and S. McDougall. 2015. Patterns of subclinical ketosis and their associations with disease and productivity in seasonal-calving, predominantly pasture-fed dairy cows in New Zealand. N. Z. Vet. J. 63:241-248.

Corson, D. C., G. C. Waghorn, M. J. Ulyatt, and J. Lee. 1999. NIRS: Forage analysis and livestock feeding. Proc. N. Z. Grassland Assoc. $61: 127-132$.

Cutullic, E., L. Delaby, Y. Gallard, and C. Disenhaus. 2011. Dairy cows' reproductive response to feeding level differs according to the reproductive stage and the breed. Animal 5:731-740.

Drackley, J. K. 1999. Biology of dairy cows during the transition period: The final frontier? J. Dairy Sci. 82:2259-2273.

Fox, D. G., C. J. Sniffen, J. D. O'Connor, J. B. Russell, and P. J. Van Soest. 1992. A net carbohydrate and protein system for evaluating cattle diets: 3. Cattle requirements and diet adequacy. J. Anim. Sci. 70:3578-3596.

Galvão, K. N., M. J. B. F. Flaminio, S. B. Brittin, R. Sper, M. Fraga, L. Caixeta, A. Ricci, C. L. Guard, W. R. Butler, and R. O. Gilbert. 2010. Association between uterine disease and indicators of neutrophil and systemic energy status in lactating Holstein cows. J. Dairy Sci. 93:2926-2937.

Garnsworthy, P. C., A. A. Fouladi-Nasta, G. E. Mann, K. D. Sinclair and R. Webb. 2009. Effect of dietary-induced changes in plasma insulin concentrations during the early post partum period on pregnancy rate in dairy cows. Reproduction 137:759-768.

Garnsworthy, P. C., A. Lock, G. E. Mann, K. D. Sinclair, and R. Webb. 2008. Nutrition, metabolism, and fertility in dairy cows: 1 . Dietary energy source and ovarian function. J. Dairy Sci. 91:3814-3823.

Gong, J. G., W. J. Lee, P. C. Garnsworthy, and R. Webb. 2002. Effect of dietary induced increases in circulating insulin concentrations during the early postpartum period on reproductive function in dairy cows. Reproduction 123:419-427.

Hammon, D. S., I. M. Evjen, T. R. Dhiman, J. P. Goff, and J. L. Walters. 2006. Neutrophil function and energy status in Holstein cows with uterine health disorders. Vet. Immunol. Immunopathol. 113:21-29.

Higgs, R. J., A. J. Sheahan, K. Mandok, M. E. Van Amburgh, and J. R. Roche. 2013. The effect of starch-, fiber-, or sugar-based supplements on nitrogen utilization in grazing dairy cows. J. Dairy Sci. 96:3857-3866.

Horan, B., P. Dillon, D. P. Berry, P. O'Connor, and M. Rath. 2005. The effect of strain of Holstein-Friesian, feeding system and parity on lactation curves characteristics of spring-calving dairy cows. Livest. Prod. Sci. 95:231-241.

Iwersen, M., U. Falkenberg, R. Voigtsberger, D. Forderung, and W. Heuwieser. 2009. Evaluation of an electronic cowside test to detect subclinical ketosis in dairy cows. J. Dairy Sci. 92:2618-2624.

Kennedy, J., P. Dillon, L. Delaby, P. Faverdin, G. Stakelum, and M. Rath. 2003. Effect of genetic merit and concentrate supplementation on grass intake and milk production with Holstein Friesian dairy cows. J. Dairy Sci. 86:610-621.

Kennedy, J., P. Dillon, P. Faverdin, L. Delaby, F. Buckley, and M. Rath. 2002. The influence of cow genetic merit for milk production on response to level of concentrate supplementation in a grassbased system. Anim. Sci. 75:433-445.

Kolver, E. S., L. D. Muller, M. C. Barry, and J. W. Penno. 1998 Evaluation and application of the Cornell Net Carbohydrate and Protein System for dairy cows fed diets based on pasture. J. Dairy Sci. 81:2029-2039.

McCarthy, S., D. P. Berry, P. Dillon, M. Rath, and B. Horan. 2007. Influence of Holstein-Friesian strain and feed system on body weight and body condition score lactation profiles. J. Dairy Sci. 90:1859-1869
McDougall, S., D. A. Clark, K. L. Macmillan, and N. B. Williamson. 1995. Some effects of feeding pasture silage as a supplement to pasture on reproductive performance in lactating dairy cows. $\mathrm{N}$. Z. Vet. J. 43:4-9.

McDougall, S., R. Macaulay, and C. Compton. 2007. Association between endometritis diagnosis using a novel intravaginal device and reproductive performance in dairy cattle. Anim. Reprod. Sci. 99:9-23.

Moller, S., C. Matthew, and G. F. Wilson. 1993. Pasture protein and soluble carbohydrate levels in spring dairy pasture and associations with cow performance. Proc. N.Z. Soc. Anim. Prod. 53:83-86.

Ntallaris, T., P. Humblot, R. Bage, Y. Sjunnesson, J. Dupont, and B. Berglund. 2017. Effect of energy balance profiles on metabolic and reproductive response in Holstein and Swedish Red cows. Theriogenology 90:276-283.

Ospina, P. A., J. A. McArt, T. R. Overton, T. Stokol, and D. V. Nydam. 2013. Using nonesterified fatty acids and $\beta$-hydroxybutyrate concentrations during the transition period for herd-level monitoring of increased risk of disease and decreased reproductive and milking performance. Vet. Clin. North Am. Food Anim. Pract. $29: 387-412$

Roche, J. R., D. P. Berry, and E. S. Kolver. 2006. Holstein-Friesian strain and feed effects on milk production, body weight, and body condition score profiles in grazing dairy cows. J. Dairy Sci. 89:3532-3543

Roche, J. R., C. R. Burke, S. Meier, and C. G. Walker. 2011. Nutrition reproduction interaction in pasture-based systems: Is nutrition a factor in reproductive failure? Anim. Prod. Sci. 51:1045-1066.

Roche, J. R., P. G. Dillon, C. R. Stockdale, L. H. Baumgard, and M. J. VanBaale. 2004. Relationships among international body condition scoring systems. J. Dairy Sci. 87:3076-3079.

Roche, J. R., N. C. Friggens, J. K. Kay, M. W. Fisher, K. J. Stafford, and D. P. Berry. 2009. Invited review: Body condition score and its association with dairy cow productivity, health, and welfare. J. Dairy Sci. 92:5769-5801.

Roche, J. R., J. K. Kay, C. V. C. Phyn, S. Meier, J. M. Lee, and C. R. Burke. 2010. Dietary structural to nonfiber carbohydrate concentration during the transition period in grazing dairy cows. J. Dairy Sci. 93:3671-3683.

Roche, J. R., E. S. Kolver, and J. K. Kay. 2005. Influence of precalving feed allowance on periparturient metabolic and hormonal responses and milk production in grazing dairy cows. J. Dairy Sci $88: 677-689$

Roche, J.R., J.M. Lee, K.A. Macdonald, and D.P. Berry. 2007. Relationships among body condition score, body weight, and milk production variables in pasture-based dairy cows. J. Dairy Sci. 90:3802-3815.

Roche, J. R., S. P. Washburn, D. P. Berry, D. J. Donaghy, and B. Horan. 2017. Seasonal pasture-based dairy production systems. Pages 99-114 in Large Dairy Herd Management. 3rd ed. D. Beede, ed. American Dairy Science Association, Champaign, IL.

Rodney, R. M., P. Celi, W. Scott, K. Breinhild, and I. J. Lean. 2015. Effects of dietary fat on fertility of dairy cattle: A meta-analysis and meta-regression. J. Dairy Sci. 98:5601-5620.

Sheahan, A. J., J. K. Kay, and J. R. Roche. 2013. Carbohydrate supplements and their effects on pasture dry matter intake, feeding behavior, and blood factors associated with intake regulation. J. Dairy Sci. 96:7818-7829.

Sheldon, I. M., D. E. Noakes, A. N. Rycroft, D. U. Pfeiffer, and H Dobson. 2002. Influence of uterine bacterial contamination after parturition on ovarian dominant follicle selection and follicle growth and function in cattle. Reproduction 123:837-845. 